\title{
Gestaltningen och etablering av Förintelseminnet i Sverige
}

\author{
Tanja Schult
}

Aвstract • Artikeln handlar om de monumenten över Förintelsens offer som restes i Sverige mellan I 949 och 1998 och kompletterar och till viss del korrigerar bilden av hur minnet av Förintelsen har vuxit fram i Sverige. Medan vissa menar att Förintelsen inte uppmärksammades alls i Sverige förrän på i 980-talet, visar artikeln att minnesmonument faktiskt restes både direkt efter kriget och under de följande decennierna. Om vi frigör oss från dagens förståelse av Förintelsen och den nu etablerade vokabulären kan vi ta till oss de tidiga verken och därmed få en mer nyanserad bild av hur minneskulturen har förändrats. Därmed kan vi också ge dem som drev monumentfrågan det erkännande som de inte tidigare fått men som de förtjänar. De tidiga monumenten är knappast kända för en bredare krets och syftet med artikeln är att göra fler uppmärksamma på deras existens. De tidiga verken ger framförallt uttryck för de överlevandens behov av att sörja sina anhöriga som blivit offer för nazisternas folkmord. Med tiden och med nya judiska invandrare och flyktingar från kontinenten växte nya behov fram som så småningom ledde till fler monument. Det blir tydligt hur minnena omförhandlas inom den judiska minoriteten som för övrigt inte var en homogen grupp. Parallellt med dessa omförhandlingar etablerades minnet av Förintelsen internationellt som en referenspunkt i historien. Tillsammans med de överlevandes och deras anhörigas engagemang blev Förintelsen en viktig referenspunkt både inom den judiska gruppen och så småningom även i det svenska majoritetssamhället (något som behandlas i del 2).

\section{Del 1. Förintelsemonument 1949-1998}

Denna artikel handlar om de minnesmärken över Förintelsens offer som restes i Sverige från I949 fram till r 998 . I ett senare nummer av Nordisk Judaistik publiceras del 2 som handlar om tiden efter 1998 (med vissa tillbakablickar). Artiklarna är ett resultat av forskningsprojektet I skuggan av Förintelsen som pågick mellan 2009-201 2. ${ }^{1}$ Fast studien ligger några år tillbaka kan den fortfarande ses som den första och hittills enda i sitt slag som försöker inventera alla i Sverige resta minnesmärken över Förintelsen. ${ }^{2}$ Studien är

1 Projektet bedrevs tillsammans med historikern Henrik Rosengren och var finansierat av Riksbankens jubileumsfond.

2 Bortsett från min egen artikel (Schult 20I6) som publicerades under tiden. Det är mycket möjligt att jag inte har lyckats att hitta alla Förintelsemonument som ett viktigt bidrag till förståelsen av framväxten av Förintelseminnet i Sverige och vill ge en röst åt dem som under flera decennier lagt stor möda på att resa dessa monument. Vidare vill den inspirera andra att ta upp ämnet.

finns i Sverige. Detta beror delvis på hur dagens förståelse av Förintelsen överskuggar alla tidigare uttryck och hur detta försvårar efterforskningen. Ibland är det inte heller klart vilka offer ett monument är tillägnat, t.ex. finns det i Helsingborg ett minnesmonument på Pålsjös krigskyrkogård över de flyktingar som kom med de s.k. vita bussarna. Korset som vaktar över minnesstenarna antyder att dessa offer var kristna men Gotlandsexemplet visar att placeringen på en kyrkogård inte utesluter att judiska offer ändå minns här. Det är alltså mycket möjligt att fler minnesmärken kan hittas - men förmodligen skulle de inte nämnvärt förändra helhetsbilden av hur minnet av Förintelsen växte fram i Sverige. 
I artikeln försöker jag frigöra mig från den Förintelseförståelse och den formvokabulär som vuxit fram sedan sent i980-tal för att kunna ta till mig tidiga verk som tillägnades Förintelsens offer, även om de, enligt dagens syn, saknar tydliga inskriptioner eller entydiga ikonografiska referenser. ${ }^{3}$ Syftet är att illustrera att det redan vid krigsslutet fanns både behov och vilja att minnas Förintelsen $\mathrm{i}$ Sverige. Dessutom blir det tydligt vad som var karakteristiskt för just Sveriges förhållande till Förintelsen samt hur och varför minnet av Förintelsen har etablerats under de senaste sju decennierna. Genom dessa monument deras gestaltning och mottagande - ges en översikt över hur minnet av Förintelsen växte fram i Sverige och hur det har förändrats sedan krigsslutet.

Minnesmärken är en särskilt lämpliggenre för att illustrera hur det omgivande samhället har förhållit sig till ett historisk skeende eftersom de konserverar aspekter som en viss grupp i samhället vid en viss tidpunkt kunde enas om. I en fysisk manifestation bevaras de värderingar som inom en viss grupp ansågs av vikt och deras förhoppning att även framtida generationer skulle bli påminda om dessa värderingar. Naturligtvis kan inte alla aspekter i den ofta komplicerade och motstridige minnesprocessen illustreras genom monument. Men att fokusera på monument är särskilt givande då de är resultat av en ofta lång process med flera beslutsfattare involverade och därmed ger insyn i hur minnen omförhandlas och kommer till uttryck. ${ }^{4}$ Därmed ger de

3 Vid tidpunkten för publiceringen hade ett viktigt bidrag tillkommit (Følners 20 I I) som behandlar de i Danmark resta monumenten över Förintelsen och de danska judarnas flykt till Sverige 1943. Følners artikel har gett några viktiga impulser som förtydligar min argumentationslinje.

4 Minnesmärken var också föremål för min doktorsavhandling (Schult 2009/20I2). För att kunna sammanfatta de stora dragen i de olika Förintelsemonumenten insyn både i det svensk-judiska minoritetssamhället, som står i fokus för del I, och i det svenska majoritetssamhällets kollektiva minne, som belyses närmare i del 2. Det blir tydligt att minnena i de olika grupperna var beroende av varandra; först när minoritetens- och majoritetens syn på Förintelsen närmade sig varandra och båda ansåg att detta historiska skeende ska minnas av alla människor finns grundförutsättningen för att monument skulle uppföras i det offentliga rummet och inte enbart på privat ägd mark. Dessutom blir det tydligt hur de olika gruppernas minnen påverkades av andra faktorer, inte minst den status och betydelse som Förintelsen hade fått internationellt. Studien av dessa monument ger därmed en inblick i hur förhållandet till Förintelsen har förändrats i Sverige under de senaste 70 åren.

\section{Sverige och Förintelsen}

På Lärbro kyrkogård på Gotland finns nio judiska gravar till nio unga judar som dog på ön r 945-1 946. De var flyktingar från Polen och Tjeckoslovakien och begravdes tillsammans med 36 kristna före detta koncentrationslägerfångar efter att de hade vårdats på Lärbros krigssjukhus. Gravarna upptäcktes av den svensk-judiske konstnären Channa Bankier under I980-talet och I 5 år senare skriver hon: "Ingen plats i hela Europa är fri från vittnesmål om Förintelsen, om kriget. Till och med i turistparadiset klingar vittnesmålen genom dessa gravar" (Bankier I 995: $65-66) .5$

många olika, ofta komplicerade och dåligt dokumenterade minnesprojekten blev jag mycket inspirerad av Assmann 2006 och Sjögren 200I.

5 Channa Bankier åker regelbundet till begravningsplatsen, lägger stenar på de judiska gravarna och försäkrar sig om att den kristna församlingen i Lärbro, som är mycket mån om gravarna, fortsätter att 
I detta turistparadis hittar vi alltså än idag tydliga spår av Förintelsen: gravarna och senare tillkomna minnesstenar samt det före detta krigssjukhuset som 2007 omvandlades till ett litet museum. Att Channa Bankier upptäcker gravarna under r980-talet men skriver om dem först I 995 - 50 år efter krigsslutet som i hela Europa leder till en rad högtidliga minnesceremonier - speglar hur minnet av Förintelsen har växt fram i Sverige. De tidiga minnena suddades ut eller föll i glömska, men Förintelsen hade ändå inte lämnat Sverige oberörd. Från 1942 kom tusentals båtflyktingar till Gotland och fram till slutet av kriget kom överlevande från Förintelsen som vårdades på sjukhuset. Bland dem som fick vård fanns också tyska soldater och av tyskarna tvångsrekryterade balter som flytt när Röda armén intog deras länder, och som mestadels utlämnades till Ryssland r 946 i den så kallade baltutlämningen.

Intill de enkla judiska gravarna finns en minnessten som Mosaiska församlingen i Stockholm (som Judiska församlingen hette fram till i 980) reste i 970. Det var den judiska minoriteten som såg till att de judiska offren skulle minnas. "Till minne av våra martyrer under nazismens år I 939-I 945" lyder inskriften. Också andra minoriteter tog sig an de sina: det finns till exempel också en sten tillägnad polacker som varit fångar i tyska koncentrationsläger och som trots räddningen till Gotland dog "till följd av sjukdom och utmattning", som det står på stenen. Den restes av det Polska Samfundet i Sverige i samarbete med den polska regeringen $2005 \cdot{ }^{6}$

sköta dem väl. Enligt e-postmeddelande från Channa Bankier till författaren (25.5.2010).

6 Den polska regeringens engagemang $i$ att efter kommunismens fall och framförallt kring millenniumskifte uppföra, i hela Europa, minnesmärken över polacker som blev offer under andra världskriget förtjäna en egen studie.
Till skillnad från resten av Europa var Sverige i stort sett förskonat från andra världskrigets stridshandlingar, men helt opåverkat av krigets och Förintelsens fasor var det inte. Minnet av kriget och Förintelsen finns även på Gotland, mitt i den idylliska provinsen lite vid sidan av, mer tydlig för den som vill och orkar se, synliggjord av gotlänningarna som rest gravstenar och ytterligare framhävt av de judiska och polska minoriteterna som långt senare, då de hade etablerat sig i sitt nya hemland, rest minnesstenar. Kriget och Förintelsen har påverkat Sverige, indirekt eller sent, ofta genom influenser utifrån, men spåren finns där, även i ett turistparadis som Gotland. Dess minne var och förblev emellertid under lång tid minoriteternas uppgift, en minoritet som var långt ifrån homogen och vars minneskultur präglades av internationella influenser.

Gotlandsexemplet är bara ett av många spår av Förintelsen i Sverige. På judiska begravningsplatser runt om i landet finns det långa rader med enkla stengravar, så kallade flyktinggravar. Människor som under våren I945 räddades till Sverige via UNRRA (United Nations Relief and Rehabilitation Administration) eller Röda korset men som var för svaga för att återhämta sig, begravdes där. Dessa gravar vittnar om unga människor, ofta kvinnor i 2o-årsåldern med tyska, polska, ungerska eller rumänska namn, som dog samma sommar de hade kommit till friheten, ofta med bara en eller två dagars mellanrum. De små församlingarna var mycket upptagna med att begrava alla dessa döda, enligt judisk sed snarast möjligt.

Bara några år efter krigsslutet restes de första Förintelsemonumenten i Sverige. Dessa monument tillkom på de överlevandes initiativ och restes i allmänhet på judiska begravningsplatser. Genom själva placeringen var tillgängligheten begränsad för icke-judar. Dessa tidiga verk riktade sig inte utanför den 


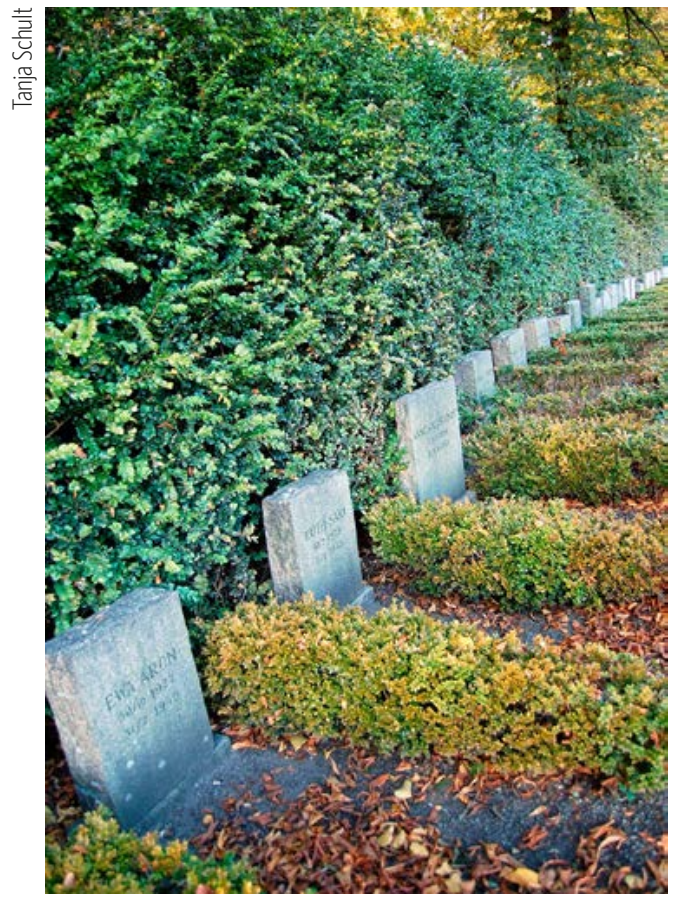

Flyktinggravar på den gamla judiska begravningsplatsen i Malmö.

egna gemenskapen och de speglade inte staten Sveriges förhållningssätt till Förintelsen utan i första hand minoritetens. Att sörja de judiska offren, som dog på svensk mark eller på kontinenten, förblev under decennier en angelägenhet främst för de svenska judarna.

Ändå vittnar både flyktinggravarna och de tidiga Förintelsemonumenten om en aspekt som kan sägas vara karakteristisk för de svenska erfarenheterna: Sverige stod utanför kriget, vilket gjorde att man oftast inte hade personliga erfarenheter från kriget och väldigt få en personlig relation till offren. Denna aspekt blir ännu tydligare om vi jämför med de monument över folkmordets offer som restes i grannlandet Norge, i Trondheim I 947 och i Oslo I 948.7 Dessa var

7 De monumenten innefattar alla namn på de, från dessa städer deporterade judar som inte kom tillbaka. Monumentet i Oslo uppfördes av den danske bildhuggaren också placerade på judiska begravningsplatser men i motsats till de svenska monumenten var de norska nationella monument i den meningen att de hade sin utgångspunkt $\mathrm{i}$ att offren var norska medborgare som efter den tyska ockupationen I 940 hade deporterats och dödats i lägren. De svenska monumenten är tillägnade utlänningar vars anknytning till Sverige bestod i att de - efter räddningen och inresan till landet - dog och begravdes här.

Ändå fanns det en samhörighets- och ansvarskänsla med och för offren hos den svensk-judiska minoritetsbefolkningen. Efter nationalsocialisternas maktövertagande hade de svenska judarna blivit medvetna om den ständigt livshotande faran, som endast tack vare den svenska neutraliteten och krigsförloppet inte blev verklighet även för dem. De svenska judarna tog hand om de överlevande som kom hit och begravde dem som dog. Genom de olika monumenten som tillkom under efterkrigstiden tog de sig också an uppgiften att sörja dem som hade dött på kontinenten, en stor uppgift och en tung börda för den lilla svensk-judiska minoriteten. ${ }^{8}$

Harald Isenstein som hade räddat sig till Sverige hösten 1943 (jmf"Högtidsdagar i Trondheim" I 947: I 86-i 87, och "Judiskt gravmonument i Oslo" 1949: 24). Isensteins minnesmärke över båtflyktingarna i Helsingborg invigdes 1945 och diskuteras i del 2; Isensteins förslag till Malmös Förintelsemonument fick avslag. Situationen var liknande för de danska judar som deporterades och dog i Theresienstadt och fick ett minnesmärke som listar de dödas namn (jmf Følners 20 I I: 2 I 9).

8 Karin Sjögren (200 I: 26) skriver i sin doktorsavhandling att omedelbart efter andra världskriget fanns det $\mathrm{I} 3$ ooo judar i Sverige -65 procent mer än före I939. Antalet judar blev, i alla fall under några år, avsevärt större än före kriget. De facto var församlingslivet i slutet av och direkt efter kriget ibland mycket mer aktivt än tidigare (och senare), framförallt på grund av de danska judarnas deltagande. Enligt Judiska 


\section{Folkmordets offer och den nygrundade staten Israel}

Att den judiska minoriteten i Sverige redan under den tidiga efterkrigstiden var mycket medveten om folkmordets karaktär och omfång illustreras av Willy Gordons Till minnet av krigets offer. Verket restes på initiativ av föreningen De 45 års räddade på den gamla judiska begravningsplatsen i Malmö r $949 .{ }^{9}$ Trots sin vaga titel är verket också enligt dagens förståelse ett Förintelsemonument och konstnären använde själv begreppet då det senare etablerats. Titeln är karakteristisk för de tidiga efterkrigsverken, där kriget fortfarande var mycket närvarande för alla.

En del av ursprungsidén var att monumentet skulle tillägnas dem som dog på svensk mark, närmare bestämt i Malmöområdet. Dit räknades de mellan 150 och 200 judar som överlevde lägren och transporten till Sverige, men dog kort därefter i Malmö. Dessutom räknade man in allierade piloter av judisk börd som störtade över Sverige samt de danska judar som drunknade under flykten över Öresund 1943. Detta förklarar varför de 15 länder som listas under verkets titel på monumentets ena kortsidan inkluderar Danmark, Australien och England där det

församlingen i Stockholm finns idag ca I 8 ooo judar i Sverige, varav ca 7000 är medlemmar i en judisk församling.

9 För monumentet se Gordons memoarer (band 5 A). Jag tackar Mona Gordon, Willy Gordons änka, för att ha gett mig tillgång till hennes makes memoarer. De spelades in på kassettband mellan I 990-talet och 2003, delvis av Willy Gordon själv, delvis tillsammans med dottern Sally, men mestadels med vännen och journalisten Jacqueline Stare. Det finns över 32 kassettband i änkans ägo. Jag stödjer mig på de band som blivit nedtecknade, minst två tredjedelar av hela materialet. Dessutom fick jag insyn i Gordons klippsamling. Se också Rubinstein I950 och Leiser I $95^{\circ}$.

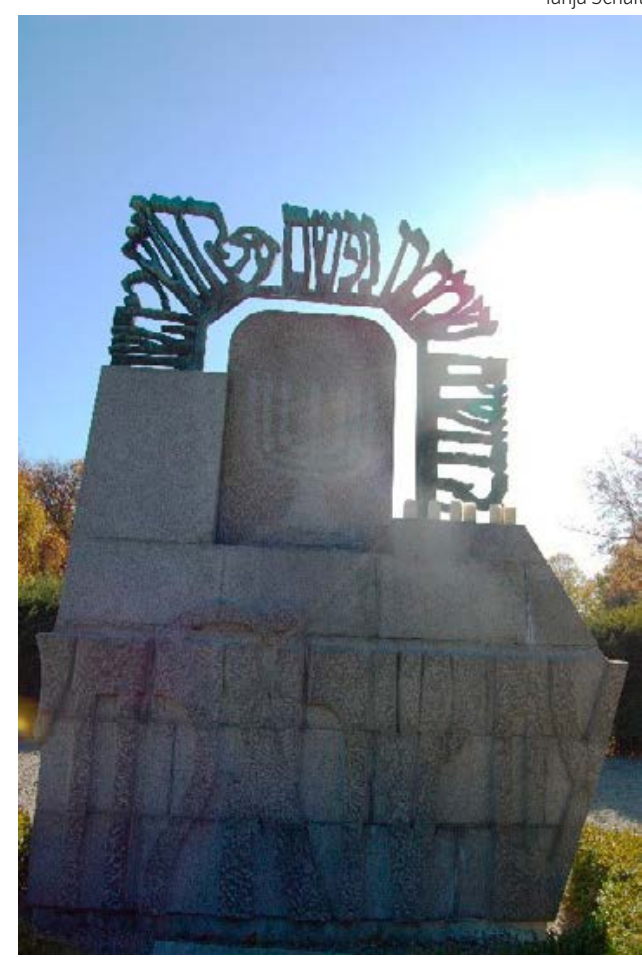

Willy Gordon, Till minnet av krigets offer, Malmö, 1949.

inte fanns några förintelseläger och där det inte förekom några dödsskjutningar. Alla dessa offer fick också individuella gravstenar på den gamla begravningsplatsen i Malmö, där sedan britterna hedrade sina judiska flygares minne med en ceremoni i 948 ("Judiska flygares minne hedrat i Malmö" I 948: 2 I 7).

Monumentets skapare, Willy Gordon ( I 9 I 8-2003), hade redan från början inkluderat alla judar som blev offer för det nazistiska folkmordet. Anknytningen till det judiska blir tydlig inte bara genom placeringen på den judiska begravningsplatsen och de hebreiska inskriptionerna, utan också genom den använda symboliken: en menora, en av judendomens äldsta symboler. De uppstaplade stenblocken kan ses som referens till klagomuren i Jerusalem, men det är framförallt genom askan från Auschwitz, vilken hämtats med officiellt tillstånd från den 


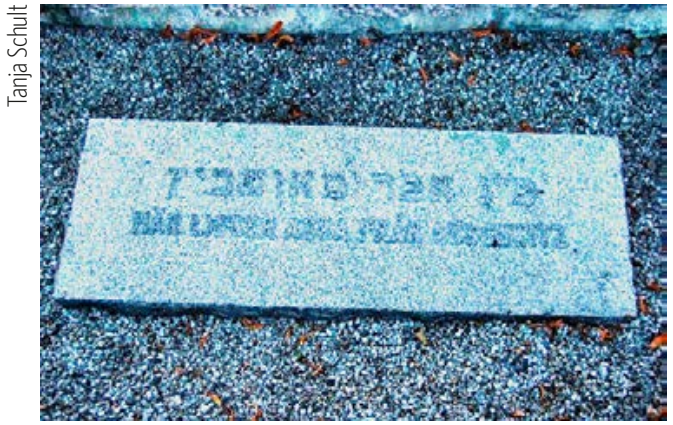

Willy Gordon, Till minnet av krigets offer, Malmö, 1949, detalj.

polska regeringen och som blivit gravsatt intill monumentet ${ }^{10}$ som verket tydligt skapar en koppling mellan offren som dog i Malmö och alla andra judiska offer som mördats av"en ond nation under åren I 933-1 945" som det står på hebreiska på en av kortsidorna. Det råder ingen tvekan om vem som avsågs med"en ond nation" och behovet att specificera förövare och offer uppstod först under I970-talet när medvetandet om det historiska skeendet hade bleknat. Askan från Auschwitz visar tydligt att monumentet är tillägnat alla offer för folkmordet och att Auschwitz redan då hade blivit en symbol för Förintelsen.

Längst upp på Gordons minnesmärke finns de genombrutna bronsbokstäverna som strävar mot himlen och bildar texten "Åt de heliga martyrerna som gav sitt liv för Gud"

10 Under efterkrigstiden fick både enskilda överlevande och monumentprojekt i många länder små urnor med jord från Förintelselägret Auschwitz-Birkenau. Uppgiften bekräftades av Elzbieta Brzozka, intendent för samlingarna i museet AuschwitzBirkenau. Enligt e-post-meddelandet från Brzozka till författaren ( 16.4 .2010 ). Efter Israels grundande blandades ibland också jord från det Heliga Landet med jord från olika koncentrationsläger och placerades i urnor vid monument, som i Warszawas gettomonument (jmf" Ghettomonumentet i Warszawa", Judisk krönika I7 (I948): 8). Bruket avskaffades dock senare, inte minst av etiska och konservatoriska skäl. (angående verket se Gordon 1976: 26; se också Leiser I 945: 387-389).”[S]kriften om det judiska martyriet svävar i rymden som ett löfte om förlossning och befrielse" (Leiser I950: I60). Enligt Rubinstein hade Gordon tänkt att monumentets övre del skulle referera till livet efter detta medan den nedre skulle stå för den "konstruktiva faktorn i judarnas historia, aktualiserad genom den unga judiska statens tillkomst" (Rubinstein I 95 O: I 2). ${ }^{11}$ Denna tolkning bekräftas av texten på den nedre delen av granitpostamentet där det står med stora bokstäver på hebreiska: "Det judiska folket lever." Meningen låter som ett manifest.

I sammanhanget är det viktigt att framhäva att det var känslan av hopp som gjorde att monumentets upphovsman kunde övervinna den konstnärliga kris som utlöstes när han fick kännedom om nazisternas barbari (jmf Hancock r 988). Willy Gordon hade kommit som barn till Sverige, som son till en kantor, och senare tillbringat långa perioder i sina föräldrars hemländer Lettland och Litauen. Under slutet av kriget fick han veta att de allra flesta av hans släktingar i Baltikum hade mördats och med dem hade också den gamla östeuropeiska judendomen och dess kultur förintats. Först när Gordon träffade flyktingar från koncentrationslägren som hade kommit till ett uppsamlingsläger i Neglinge utanför Stockholm, fick han sin konstnärliga drivkraft tillbaka. Enligt hans memoarer sjöng de överlevande olika så kallade gettosånger som t.ex."Mir lebn ejbig”(Vi kommer att leva evigt). Deras överlevnadsvilja och inre motståndskraft påminde Gordon om den anda som han hade lärt känna under sin gymnasietid i Baltikum. Det var möten med de

11 I memoarerna beskrev Gordon monumentet i liknande ord: "Jorden är till för människorna och himlen är till för Gud" (band 24: s. 8, utskrift av Ulla Terling, jag följer hennes numering). 
överlevanden som övertygade honom om att det ändå var meningsfullt att skapa konst och att han hade ett viktigt budskap att förmedla.

Medan folkmordet gjorde det omöjligt för Gordon att skapa var det alltså de överlevandes livsvilja som lärde honom att hålla fast vid konsten som ett uttryck för humanismen. ${ }^{12}$ De överlevande kan mycket väl ha haft direkt inflytande på valet av inskriften: "Det judiska folket lever." Trots all smärta och trots folkmordets omfång kände Gordon en viss tillfredsställelse över att han fick göra monumentet. ${ }^{13}$ Det var viktigt för honom att markera att nazisterna, trots allt, inte hade kunnat fullfölja sina planer på att utrota alla judar i Europa. ${ }^{14}$

Gordons monument fyllde under efterkrigstiden en viktig funktion då den erbjöd en konkret plats att sörja på. Ett skäl till att hans Till minnet av krigets offer fortfarande har en stor betydelse för judarna i Malmö är att det lyckas fånga upp de aspekter som egentligen först under de efterföljande decennierna utkristalliserades som avgörande för de flesta judars identitet i Sverige: Förintelsen och staten Israel. Det är förmodligen denna omständighet som gör att man, till skillnad från församlingarna i Stockholm och Göteborg, inte upplevde något behov av något nytt monument. ${ }^{15}$ Gordon lyckades att i ett och

$12 \mathrm{Jmf}$ memoarer, band I 3 A, utskrift av Ulla Terling, s. 8 och s. I3.

13 Gordon nämner monumentet med liknande ord vid olika tillfällen i sina inspelade memoarer. Se t.ex. band 5 A, I 3 A och I 7 (numreringen följer utskrifterna). Gordon skriver att uppdraget var"en kolossal hedersuppgift" (band 24: s. 8).

14 Ordvalet återfinns också i Gordons memoarer: "Monumentet på kyrkogården [sic] i Malmö var ett uttryck för, ett manifest för att vi lever, ni [nazisterna] har inte lyckats.” Jmf band 5. Se också band 24, s. 8: "Den nazistiska viljan att utplåna det judiska hade misslyckats."

15 Dessutom är verket visserligen placerat samma monument koppla ihop Förintelsens fasor och dess identitetsförpliktande betydelse för judarna med staten Israel, som hade grundats ett år innan verket invigdes. Staten Israel ansågs av många som en nödvändig och rättvis konsekvens av folkmordet: de oskyldiga offren hade inte dött förgäves utan omvandlades postumt till martyrer som hade gett sina liv för en högre uppgift: ett slut på diaspora-tillvaron och en judisk stat som i framtiden skulle säkerställa judisk fortlevnad. För Gordon, liksom för många judar i Sverige, blev grundandet av den moderna staten Israel en synnerligen betydelsefull händelse som lovade en ljusare framtid och en säker tillflyktsort.

\section{Sorgearbete bland judar i Sverige}

Trots de nya ljusare tider som grundandet av staten Israel gav löfte om var sorg den dominerande känslan hos de flesta judar i Sverige. Direkt efter kriget saknades ofta ord för att ge uttryck för sorgen över de döda, men den krävde ändå konkretisering. De första Förintelsemonumenten i Sverige restes på begravningsplatser, inte minst av praktiska skäl: begravningsplatserna ägdes av församlingarna och förmodligen behövdes det inget tillstånd från staden eller kommunen för att uppföra dem. Ett annat skäl till denna placering var sannolikt den efter kriget dominerande känslan av sorg. Det enkla men eleganta minnesmärket på Östra judiska begravningsplatsen i Göteborg ger uttryck för smärtan över så många oskyldiga människors död: "Rakel begråter sina barn" står det under

på en begravningsplats, men i motsats till de andra judiska begravningsplatserna där det finns minnesmärke över Förintelsen offer, ligger Malmös gamla begravningsplats relativt centralt och på gångavstånd från synagogan. Sedan I 979 finns en ny begravningsplats som ligger i stadsdelen Rosengård. 


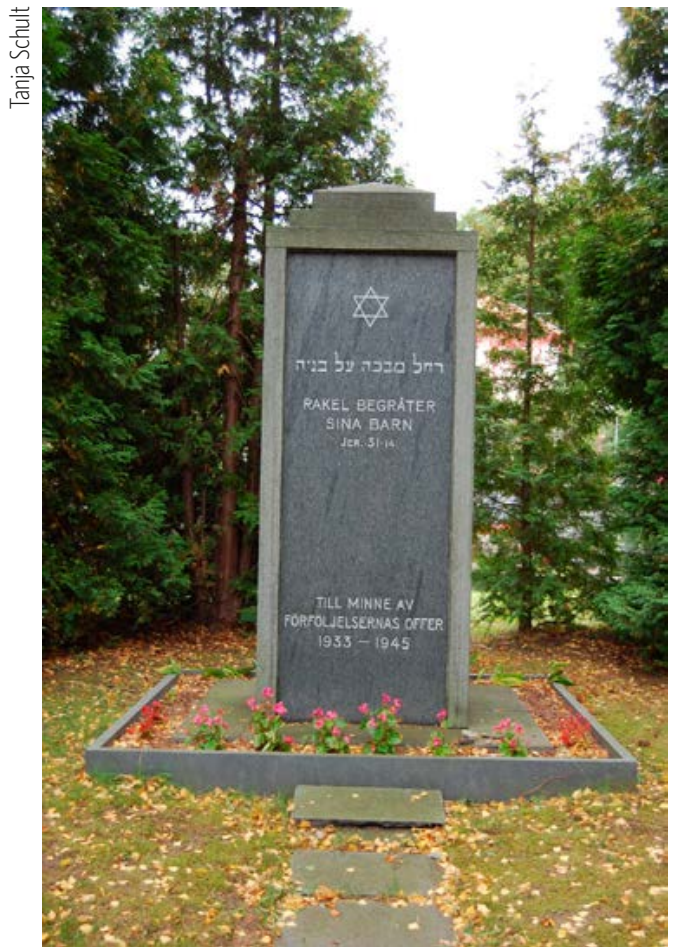

Rakel begråter sina barn (Göteborg 1949).

en Davidsstjärna, på hebreiska och på svenska. Den bibliska textpassagen lyder i sin helhet: "Så säger Herren: Rop hörs i Rama, klagan och bitter gråt: Rakel gråter över sina barn. Hon låter inte trösta sig, ty hennes barn finns inte mer." Monumentets form anknyter till en välkänd tradition inom gravarkitekturen: kenotafen, som reses över offer vars kvarlevor finns på annan ort, en surrogatgrav.

Behovet av att ha en konkret plats där man kunde sörja anhöriga vars sista vila var okänd eller vars gravar fanns i länder som var omöjliga för de överlevande att besöka är en viktig anledning till att Förintelsemonument uppfördes. Det gäller inte minst de privata minnesmärkena som t.ex. Georg Spitzmans blygsamma Till minne av min familj, som tillkom under I970-talet. ${ }^{16}$ En kollega till

16 Jag tackar Daniel Jonas, kanslichef på Judiska församlingen i Göteborg för bilder av och texten om verket samt Georg Spitz-
Spitzman, också han en överlevande, hjälpte till med formgivningen: en kombination av en enkel gravstensliknande formation och en sarkofag i miniatyr som kröns av en Davidsstjärna, och vilar på en trappliknande upphöjning. På vardera sidan av sarkofagen finns tre ljushållare. Antalet är symboliskt och representerar de sex miljoner judar som mördades under Förintelsen. I den lilla kistan ligger askan från jord som Spitzman hade hämtat vid ett privat besök i Auschwitz och som han låtit bränna i en industriugn på sitt arbete på SKF (ursprungligen: Svenska kullagerfabriken). ${ }^{17}$ I Israel lät han ingravera de

man för att ha besvarat mina frågor vid en telefonintervju (26.3.2010).

17 Meningar går isär om kriget förlängdes med några månader genom att Sverige, Nazitysklands största handelspartner, levererade kullager och järnmalm till Tyskland. Under de senaste åren har just kullagerleveransen fungerat som en laddad metafor för Sveriges profiterande på kriget. Brännandet i en SKF-ugn väcker därför ett visst obehag. Man blir påmind om debatten kring Peter Eisenmans minnesmärke i Berlin när det blev känd att företaget Degussa AG hade fått i uppdrag att utföra stelarnas klotterskydd. I Nazityskland hade kemibolaget Degussa tillverkat giftet Cyklon B som användes i förintelselägren. Men en liknande debatt uteblev helt i Spitzmans fall; han, en överlevande, hade gjort verket på eget initiativ och använde sig helt enkelt av ugnen som fanns till hans förfogande. Ingen skugga ska falla över honom. Verket var dessutom i privat ägo fram till 2008 när det placerades i entrén i det judiska församlingshusets i Göteborg (vi ska återkomma till verkets nya placering i del 2). Det kan emellertid konstateras att de olika svenska företag som profiterade på kriget till dags dato inte genomgått en ordentlig granskning (jmf Selling 20 Io: 554). När vi talar om ett specifikt svenskt förhållningssätt till Förintelsen kan ickegranskning eller profit som inte ledde till några konsekvenser förmodligen anses som typiskt svenskt. 
ur dåtidens överlevandes perspektiv: tanken att så många oskyldiga människor, däribland en och en halv miljon barn, skulle ha dött en meningslös död var för de flesta överlevande omöjlig att uthärda. Följaktligen tilldelades offren i efterhand status som martyrer och deras död omvandlades till ett aktivt agerande;18 de dog alltså för någonting högre, det judiska folket eller staten Israel. Att närma sig trauman genom att se offren som heroiska var för många en nödvändighet för att kunna leva vidare (jmf Assmann 2006: 72-8 I).

Litteratur- och kulturvetaren Aleida Assmann framhäver att det grekiska ordet martyrion ursprungligen betydde vittnesberättelse över en annan människas offerdöd. Det är alltså inte enbart den våldsamma döden utan vittnesmålet om den som konstituerar martyren, eftersom det är just den efterföljande berättelsen som definierar meningen med de mördades död. Maktlösheten och förintandet genom döden omtolkas till ett vittnesmål om våldet och det vittnesmålet övervinner döden. För att ett trauma ska kunna omvandlas till något meningsskapande (i Assmanns terminologi till triumf) krävs det

18 Till en viss del är det en efterhandskonstruktion att alla som dog i Förintelsen var judar. Det var den nazistiska raspolitiken som avgjorde vem som var jude, inte offren själva eller de religiösa judiska lagarna. Alla som dog efter nazisternas definition betraktades dock i efterhand som judar. Det är ytterst problematisk att nazisternas synsätt på så sätt lever kvar eftersom det betyder att nazisternas definition väger tyngre än offrens självvalda identitet (som t.ex. konverterad kristen eller ateist osv.) Jmf Benz 2007: 30, I 43. Att de tidiga inskriptioner av monument inte betecknar offren explicit som judar hänger ihop med att de historiska skeendena var i färskt minne, och att man ofta medvetet tog avstånd från nazisternas kategoriseringar. Detta diskuteras närmare i del 2. någon som vittnar om martyrdöden (enligt Assmann 2006: 87-88). Det är de överlevande som - i minnesmärken genom konstnären - fungerar som det berättande vittnet och därmed håller minnet av de mördade vid liv och ger deras död mening. Mot denna bakgrund kan Gordons monument i Malmö ses som ett paradexempel på synen på offren som martyrer, då hans konstnärliga gestaltning förenar trauma med motstånd och till och med någon form av slutgiltig seger. Jag påminner här om inskriften på den nedre delen av granitpostamentet: Det judiska folket lever - nazisternas avsikt att mörda alla judar hade ändå misslyckats. ${ }^{19}$

\section{Förintelsen, Israel och svensk-judisk identitet}

Många svenska judars relation till staten Israel blev med åren mer komplicerad. De positiva förväntningar som statens grundande väckte gav vika för en tillnyktring, men under efterkrigstiden var kopplingen mellan Förintelsen och vikten av att solidarisera sig med den första judiska nationalstaten vanlig. Vid min genomgång av Judisk krönika åren I 945-I 953 framgår det tydligt att det under de första $I-2$ åren var andra världskrigets och folkmordets efterverkningar samt flyktingpolitiken som dominerade rapporteringen. Något senare blev frågan om Palestina, grundandet av staten Israel och dess vidare öde och uppmaningar att stödja landet mer framträdande. In sin doktorsavhandling Judar $i$ det svenska folkhemmet. Minne och identitet i Judisk krönika 1948-1958, visar Karin Sjögren att Judisk krönika under I 950talet var "den sionistiska rörelsens främsta språkrör i Sverige" (Sjögren 200I: I 7).

$19 \mathrm{Jmf}$ fotnot I 4 . 
Inte bara majoritetsbefolkningen var fylld av framtidsanda och tilltro till ekonomisk tillväxt, också minoritetsbefolkningen fokuserade på livet och framtiden. Deras motiv därtill var emellertid ett annat; ibland var det förträngning, ibland ren självbevarelsedrift. Förintelsen hade visat judarna att deras identitet alltjämt bestämdes av andra, med katastrofala konsekvenser som följd. En effekt av denna insikt var att många kände sig tvingade att ge upp tron att assimilation var möjlig. Många, som exempelvis Harald Rubinstein (med hänvisning till filosofen Emil Fackenheim) ansåg att "assimilationen är en form av förintelse av det judiska folket och är alltså efter Auschwitz också otillåtet” (Rubinstein r 986: 6). Enligt Rubinstein kunde en ny förintelse bara undvikas genom staten Israels fortlevnad och stöd till Israel ansågs vara av yttersta vikt. Under decennierna efter krigsslutet, oavsett om man var religiös eller ej, kände sig många judar förpliktigade till solidaritet med andra judar, tvungna att uppmärksamma alla former av antisemitism och att tyda signalerna tidigt så att man aldrig mer skulle bli offer (jmf också Assmann 2006: I 4, 66). Att stödja staten Israel blev för många judar under efterkrigstiden en självklar konsekvens av Förintelsen.

En gåva till staten Israel eller till nationalfonden Keren Kajemet blev också många svenska judars sätt att hedra Förintelsens offer. Keren Kajemet samlade under efterkrigstiden in pengar till Israel och till "Martyrernas skog" (invigd I95 I, fler minnesskogsprojekt följde) där sex miljoner träd skulle planteras för att hedra de 6 miljoner offren. Martyrernas skog blev ett" grönskande minnesmärke" som både illustrerar viljan att minnas de döda och att stödja judisk gemenskap över nationella gränser och i synnerhet staten Israel. Alla som donerade träd kunde lämna in uppgifter om avlidna anhöriga, vilka registrerades i nationalregistret i Yad Vashem

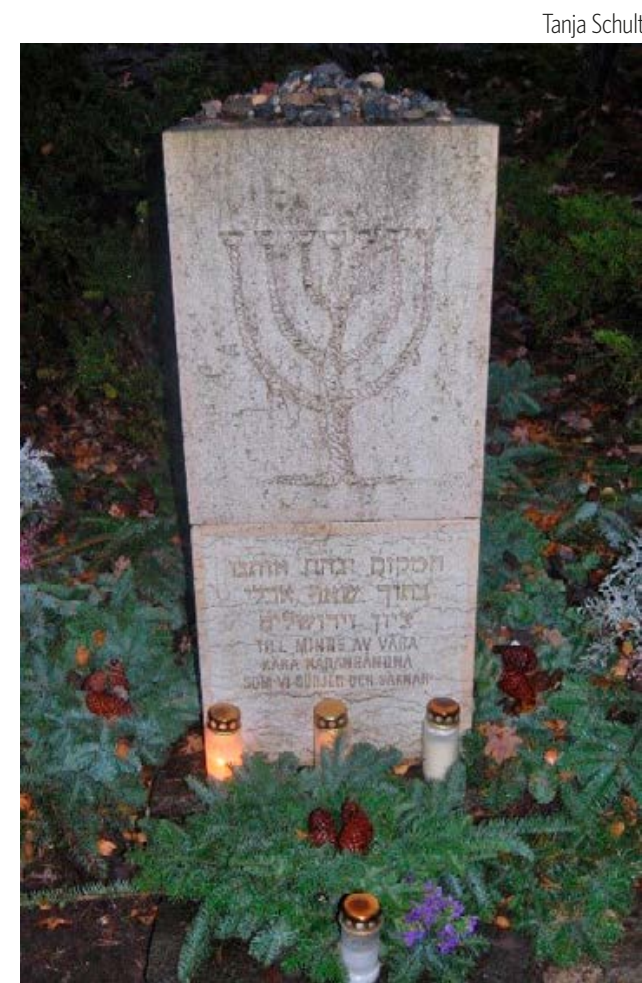

Stenen som Keren Kajemet skänkte till Stockholms församling 1984.

och sedan postumt fick israeliskt minnesmedborgarskap. Alla dessa namn publicerades också i Judisk krönika och utgör en tidig föregångare till senare tiders namnmonument (jmf Sjögren 2004: särskilt I I 6-I I 7). ${ }^{20}$

Med kunskap om Keren Kajemets verksamhet förstår man att även den ljusa granitstenen som fonden skänkte till Stockholms församling I984 faktiskt är ett Förintelsemonument, även om inskriften på stenen inte har någon direkt hänvisning till Förintelsen. Man får snarare intrycket att den tillägnas de döda i allmänhet: "Till minne av våra kära hädangångna som vi sörjer och saknar" lyder inskriften. Att det ändå är ett minnesmärke för Förintelsens offer blir emellertid tydligt

20 Under tiden har Keren Kajemet planterat fler än 230 miljoner träd i Israel, se deras hemsida. 
om man konsulterar omslaget på Judisk krönika från februari 1985 som visar en bild från invigningen och en bildtext där det står att "minnesstenen" är tillägnad "nazismens 6 miljoner judiska offer" (se omslagsbild av Judisk krönika 53(I) (1985), något mer står det dock inte om stenen i det numret). Detta minnesmärke är, som Seth Neuman skriver, en andaktsplats för att sörja de "anhöriga vilkas öden under r 9oo-talet förblivit okända" och fyller således samma funktion som kenotafen i Göteborg. Dessutom understryker stenen från Israel "samhörigheten mellan diasporans judar i Sverige/Europa och judarna i Israel" (Neuman r 998: 54). Återigen bekräftas kopplingen mellan Förintelsen och staten Israel.

\section{Vårdandet av minnet av Förintelsen och monument i bruk}

Under alla år har de olika monumenten till minne av Förintelsens offer i Malmö, Göteborg och Stockholm tjänat som samlingspunkter för minnesceremonier. Även om det är svårt att avgöra huruvida alla minnestunder hållits under alla år, är det tydligt att de har haft en stark förankring i respektive församling. ${ }^{21}$ Stenen som Keren Kajemet skänkte fungerar exempelvis som samlingspunkt vid minneshögtider för medlemmar av Föreningen Förintelsens Överlevande (FFÖ). 22 Varje söndag före Yom Kippur

21 Att så verkar vara fallet för Göteborg bekräftades i samtal med föreningens medlemmar. Att minnesstunder hölls årligen i Malmö noterades i Föreningen 1945 års räddade judar i Malmö. 40-årsjubileum 1946-1986 (I 986: I 7) och bekräftades genom samtal med församlingens medlemmar.

22 FFÖ är en rikstäckande organisation som samlar överlevande från Förintelsen och deras barn. Se deras hemsida. samlas de vid stenen för att be. Samma dag håller de också en minnesceremoni för Förintelsens offer på Norra begravningsplatsen. ${ }^{23}$ På samma sätt samlas medlemmar ur Göteborgs och Borås församlingar årligen före Yom Kippur vid minnesstenen Rakel begråter sina barn. Traditionen bröts inte ens när ett nytt Förintelsemonument invigdes 2009. Före invigningen av det nya Namnmonumentet som restes intill synagogan mitt i centrala Göteborg samlades man återigen på begravningsplatsen vid 1949 års monument.

Att Förintelsen inte fallit i glömska bland svenska judar framgår också av den uppmärksamhet man ägnade åt flyktinggravarna i Stockholm och Göteborg vid olika städdagar då man gemensamt vårdade gravarna. ${ }^{24}$ Ännu tydligare vittnen är de tillägg som gjorts på gravstenarna. Dessa ger insyn i väldigt privata minnen som blev offentliga och därmed en del av den svensk-judiska minoritetens kollektiva minne. Sedan I 970-talet har det blivit allt vanligare att man, då en anhörig avlidit, på gravstenen också lagt till namn på anhöriga som dödats i Förintelsen. Dessa tillägg visar att sorgen och minnena efter de anhöriga inte har fallit i glömska och att man har haft behov att ge minnena och sorgen ett konkret uttryck när möjlighet gavs. Viktigt i sammanhanget är att komma ihåg att judiska gravstenar - i motsats till kristna - inte är tidsbegränsade utan är tänkta att stå för all framtid. Namnen bevaras således till efterföljande generationer som ska vårda och minnas dem.

23 Enligt FFÖs ordförande, Jakob Ringart. E-postmeddelande till författaren (I6.II.2009).

24 Olika notiser förekommer i Judiska krönika under i 980-talet; se också Sommerfeld I987. 
Formuleringarna på dessa tillägg varierar och ibland är de vaga som till exempel i uttrycken att offren "omkom under andra världskriget" eller "omkom i Auschwitz". Dessa formuleringar kritiserades ibland eftersom de tycktes jämställa Förintelsens offer med människor som hade omkommit i en trafikolycka. Ibland betecknas de mördade som martyrer. Det är möjligt att man genom detta ordval ville ta avstånd från begrepp som "mördades" eller "folkmord" eftersom dessa ord skulle ha varit alltför smärtsamma att se vid besök vid begravningsplatsen. Orden återspeglar det dåvarande språkbruket som i sin tur speglar den dåvarande synen på Förintelsen.

\section{Förintelseminnet i förändring}

Under de år då inga nya monument tillkom växte så småningom nya behov fram inte minst därför att nya judiska immigranter anlände. Överlevande och flyktingar kom till Sverige främst i tre vågor - I 945 efter krigsslutet, I 956 efter revolten i Ungern och r 968/r 969 från Polen efter de antisemitiska attackerna. Detta innebar att de överlevandes öden inte heller var desamma, och inte heller deras förhållande till det judiska. Många av dem, inte minst de polska judarna som hade kommit till Sverige först under sent I960-tal, var inte religiösa och blev ofta inte heller medlemmar i de judiska församlingarna (angående de polska judarna som kom efter I968, se Dahl 2013). De hade inte varit med när de tidigare monumenten restes och hade därför ingen relation till dem. De längtade efter en plats där deras smärta och sorg kunde få komma till uttryck. Samtidigt blev det med åren allt svårare för de nu till åren komna överlevande och deras anhöriga att ta sig ut till begravningsplatserna och ännu mer att resa utomlands till före detta läger och gravar. Många önskade sig ett monument på en mer central plats.

Därtill kom den förändrade inställningen till Förintelsen i det svenska samhället i allmänhet som hade påverkats av utvecklingen av minneskulturen i andra länder. Under I980- och framförallt I990-talet, erkändes Förintelsen som en brytpunkt i historien i många europeiska länder som ansågs av allmänmänsklig betydelse. Detta skedde också i Polen där många överlevande hade sina rötter och dit inbjöds nu en del att delta i minnesoch försoningsceremonier. Huvudfrågan för dem blev hur minnet av folkmordet skulle bevaras när de sista överlevande inte längre var i livet, inte minst i de länder där de överlevande hade tillbringat merparten av sina liv. Frågan om ett nytt Förintelsemonument och var det skulle placeras blev aktuell.

r 994 började Romuald Wroblewski, son till en överlevande, tillsammans med andra överlevande som Halina Neujahr, samla in namn på mördade släktingar bland i Sverige bosatta överlevande för ett planerat monument (jmf Stugart I995). Idén förankrades samma år hos Föreningen Förintelsens Överlevande (FFÖ) som hade grundats I99I (Wroblewski r 995: 59). Startpunkten för projektet, som 1998 resulterade i det i Stockholm resta monumentet Glöm oss inte, var Wroblewskis svärmors resa till Polen hösten I 993, vars ändamål var att leta efter familjemedlemmars gravar från andra världskriget. Gravarna var dock borta och de fick i stället rådet att sätta upp en minnestavla på en mur vid begravningsplatsens ingång. Efter hemkomsten till Sverige beslöt familjen emellertid att man hellre ville ha en sådan minnestavla hemma i Stockholm, där familjemedlemmarna var bosatta och kunde samlas för att sörja sina anhöriga. Här möter vi samma behov som i Spitzmans privata minnesmärke. Men Wroblewski förstod att han och hans familj inte var de enda som hade detta behov"utan att det var ett problem som 
många har försökt att lösa under de gångna 50 åren men inte lyckats" (Wroblewski I 995: 57). 25 Monument på andra platser, som det i Warszawa över gettoupproret eller stenfältet i Treblinka, hade länge fyllt en viktig funktion för de överlevande. Dit hade man kanske kunnat åka och lägga stenar när man inte hade några gravar att gå till. Men de överlevande blev allt äldre och resandet alltmer besvärligt. Den kanske viktigaste orsaken var att de överlevandes hem numera fanns i Sverige. Det var här deras minnen skulle manifesteras.

Generationsskiften är en viktig anledning till att överlevande eller deras barn börjar berätta, skriva ner sina minnen eller engagera sig i monument. De inser att deras livstid är begränsad och att det finns en risk att deras erfarenheter glöms bort efter deras död. De kommer inte längre själva att kunna förmedla sina erfarenheter och behöver därmed konkreta vittnesmål som bevarar deras minnen för kommande generationer. Monument upplevs av många som ett uttryckssätt som förpliktigar nästa generation att hålla minnet levande, framförallt om de finns på en relevant plats och hålls levande genom minnesceremonier (Assmann 2006: 34-35). Samtidigt är monument genom sin fysiska gestaltning, karaktär och placering på en för allmänheten tillgänglig plats också en form av officiell bekräftelse, ett erkännande av lidandet. Det dröjde dock till 2009 innan ett Förintelseminnesmärke restes på en icke-privatägd, offentlig plats (mer om detta i del 2).

Generationsväxlingen var också den omedelbara orsaken till att Romuald Wroblewski började engagera sig i monument-

25 Jag vill tacka Svante Hansson för att ha överlämnat en omfattande materialsamling med dokument han fått av Judiska församlingen i Stockholm om monumentet Glöm oss inte, bland annat korrespondens och protokoll men också skisser, tidningsartiklar m.m. projektet. Hans fars bortgång i mars 1993 förändrade hans perspektiv och han besökte nu regelbundet faderns grav. Vid sina vandringar på begravningsplatsen lade han märke till de ovan beskrivna tilläggen på gravar om anhöriga som hade mördats i Auschwitz. Han undrade: "Vart går de som inte har några gravvårdar med sina förintade familjemedlemmars namn? Namn och minnen som de har burit på i över ett halvt sekel!" (Wroblewski r 995: 58). Wroblewski fortsätter sedan med att citera sin insändare i Judisk krönika från 1994 där han skriver att det "ej har funnits (så vitt jag vet) någon gemensam minneslund eller gravvård för att hedra dem i Holocausten [sic] dödade och försvunna. Jag föreslår därför att ett sådant monument (kan vara en enkel mur) sätts upp till deras minne. Vi får ej glömma denna generation som försvann under andra världskriget men som ändå kom med oss till Sverige.” Detta är lite förvånande, då det ju, som framgår av denna artikel, fanns en rad minnesstenar både på Norra och Södra judiska begravningsplatsen som hedrade Förintelsens offer. Dessutom var, vilket Wroblewski själv noterar, ytterligare ett verk redan under uppförande, Monument med judiska församlingens minnesplaketter. ${ }^{26}$

Detta verk, som invigdes I995, fick emellertid aldrig något större genomslag i Stockholmsförsamlingen. Bara I 2 I familjer lämnade in uppgifter om sina mördade släktingar. ${ }^{27} \mathrm{På}$ plaketterna finns alltså endast en

26 Enligt Jakob Ringart var projektet ett initiativ av Klas Haendler. E-postmeddelande till författaren (I6. I r.2009). Det finns dock en notis i Judisk krönikas bilaga Magasinet där det står att Josef Aplehag i slutet av I980-talet hade tagit initiativet till projektet (jmf Magasinet I 991: 2).

27 Vid invigningen fanns ca 80 plaketter realiserade, resten sattes dit under 1995 . Enligt e-postmeddelande från Lennart Nussdorf, verksam vid ekonomiavdelningen på Judiska församlingen (I 8.I I.2009). 
bråkdel av de över 8000 namn som senare samlades in till minnesmärket Glöm oss inte och som invigdes I 998 intill Stora synagogan i Stockholm. Vissa namn förekommer endast här på Södra begravningsplatsen medan andra också finns med på det senare uppförda monumentet intill Stora synagogan, där man inte hade någon begränsning av antalet namn som varje familj fick lämna in. På en större bronstavla syns, liksom på vissa tidigare monument, en menora samt en text på hebreiska och svenska: "Till evigt minne av våra anhöriga, Förintelsens offer, I939-45. Minns - förgät ej."Tavlan och plaketterna är monterade på en vägg av röda tegelstenar intill gravkapellet. Här som i den senare utförda Glöm oss inte är det enbart krigsåren som omfattas, inte åren efter att nazisterna kommit till makten, I 933, och började förfölja judar, först i Tyskland och sedan i Österrike, I 938.

Monumentet på Södra judiska begravningsplatsen skulle kunna beskrivas som ett misslyckande med tanke på att inte fler församlingsmedlemmar valde att vara med. Men resultatet övertygar ändå. Verket är egentligen ofullbordat, men just häri ligger dess styrka. Betraktaren hinner läsa alla namn som finns med på plaketterna. De står i ögonhöjd, på en avskild plats, där man kan vara helt ensam. Trots kritiker som befarar att Förintelseförnekare skall använda det här blygsamma verket som bekräftelse på att Förintelsen aldrig har ägt rum, är det just fătalet namn som berör så starkt eftersom de för tankarna till det stora antalet namn som saknas och därmed återspeglar det tomrum som folkmordet lämnade efter sig. Det fanns oro hos FFÖs medlemmar att verket på Södra judiska begravningsplatsen skulle spela revisionisterna i händerna. ${ }^{28}$ Men det är dock osannolikt att de

28 E-postmeddelande av Jakob Ringart till författaren (I6.I I.2009).

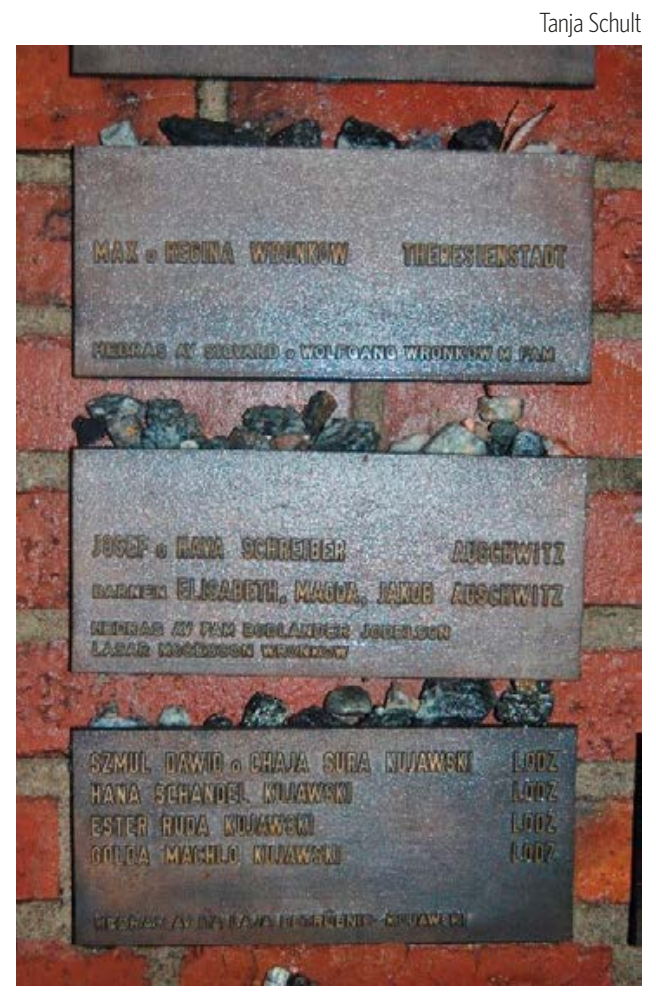

Monument med judiska församlingens minnesplaketter på Södra judiska begravningsplatsen i Stockholm, invigd 1995, detalj.

skulle låta sig påverkas av något monument överhuvudtaget. Det senare utförda Glöm oss inte med sina flera tusen namn skulle de förmodligen inte heller acceptera som bevis för att Förintelsen har ägt rum. De facto är inget av de utförda namnmonumenten i sedvanlig mening ett historiskt dokument över vad som hände under andra världskriget, även om FFÖs ordförande Jakob Ringart hävdar detta (se Ringart I999: I I och Holmén 1998). Namnen har aldrig granskats utan godtogs bara så som de kom in. Monumenten fungerar snarare som ett dokument över hur det som hände under kriget blev ihågkommet av de överlevande. Detta är av vikt och måste understrykas - inte för att ifrågasätta de inkomna namnen utan för att vi skall förstå att dessa monument inte enbart är ett minne över ett historiskt skeende utan också ett vittnesmål om dem som vill minnas. 
Namnen på dessa monument har i första hand ett symboliskt värde. Även om endast en bråkdel av de många miljoner människor som mördades namnges, får de representera också dem vars namn inte finns med. Ifråga om Stockholmsmonumentet blir detta särskilt tydligt genom att också t.ex. Janusz Korczaks namn finns med. Vetskapen om honom kom till Sverige inte minst genom Wroblewskis far, som hade arbetat som lärare i Korczaks barnhem i Warszawas getto. Tack vare att Korczak hade ordnat arbete för fadern utanför Warszawas getto, undkom denne deportationen den 5 augusti i 942, i vilken Korczak själv och de nära 200 föräldralösa barnen fördes till Treblinka där de mördades. Wroblewskis far var den ende av barnhemmets personal som överlevde. Han kunde senare emigrera till Sverige där han var med och grundade det svenska Korczaksällskapet. ${ }^{29}$

Wroblewski och hans medarbetare tog avstånd från projektet på Södra judiska begravningsplatsen. De ansåg projektet, både p.g.a. dess utformning och placering som icke övertygande, och det förtjänade inte, enligt deras åsikt, att kallas monument. De menade att verket speglade församlingens inställning till Förintelsen, vilken de fann oacceptabel. De till antalet få och av de överlevande själva bekostade plaketterna kunde enligt dem inte ersätta ett större namnmonument på en mer central plats. Diskussionen kring ett adekvat monument fortsatte.

\section{Smärtsam väg till homogeniseringen av Förintelseminnet bland svenska judar}

Det gällde att påskynda det nya monumentets uppförande. Många överlevande hade redan hunnit avlida och kunde inte längre lämna uppgifter om sina mördade släktingar. På det

29 Jag tackar Romuald Wroblewski för kritisk läsning av manuskriptet. nya monumentet skulle det finnas så många namn som möjligt, antalet namn skulle inte vara begränsat till de allra närmaste släktingarna utan alla anhöriga samt nära vänner (som vi såg med Korczak) skulle kunna uppges. Dessutom skulle ytterligare uppgifter om födelse- och dödsorter finnas med för att visa att offren kom från många olika länder och var olika gamla när de deporterades och dödades, på ett fåtal platser.

Vidare ansågs det av vikt att projektet inte skulle bekostas av de överlevande själva. Till organisatörernas besvikelse blev man dock senare tvungen att ändå vända sig till de överlevande och deras anhöriga för att be om bidrag. ${ }^{30}$ Efter många allvarliga konflikter bland medlemmarna i monumentprojektet var detta droppen som gjorde att monumentets initiativtagare Romuald Wroblewski lämnade projektet. Han ville inte riskera att monumentet inte skulle förverkligas, men ansåg att det var helt fel att göra uppgiftslämnarna till finansiärer. Han avgick från sin post i FFÖs styrelse och grundade en annan organisation som arbetade för att hålla minnet av Förintelsen levande. ${ }^{31}$

30 Jmf t.ex. minnesanteckningar från mötet mellan representanter för Judiska Församlingen och FFÖ (ro.6.r 994) (Svante Hanssons material), där det understryks att man inte ser uppgiftslämnarna som finansiärer till projektet, samt uppropet från december I 996 där FFÖ uppmanar alla som ville hedra sina förlorade anhöriga under Förintelsen att visa sin generositet.

31 Enligt telefonsamtal med Romuald Wroblewski (1 9.9.20 Io). Enligt Wroblewskis uppskattning var summan de överlevande bidrog men dock liten och inte avgörande för att monumentprojektet kunde förverkligas. Han grundade Föreningen för Förintelsens Minne där också icke-judar och icke-överlevande kunde vara med samt organisationer och skolor. Föreningen var aktiv fram till 2005 . FFÖ består fortfarande. 


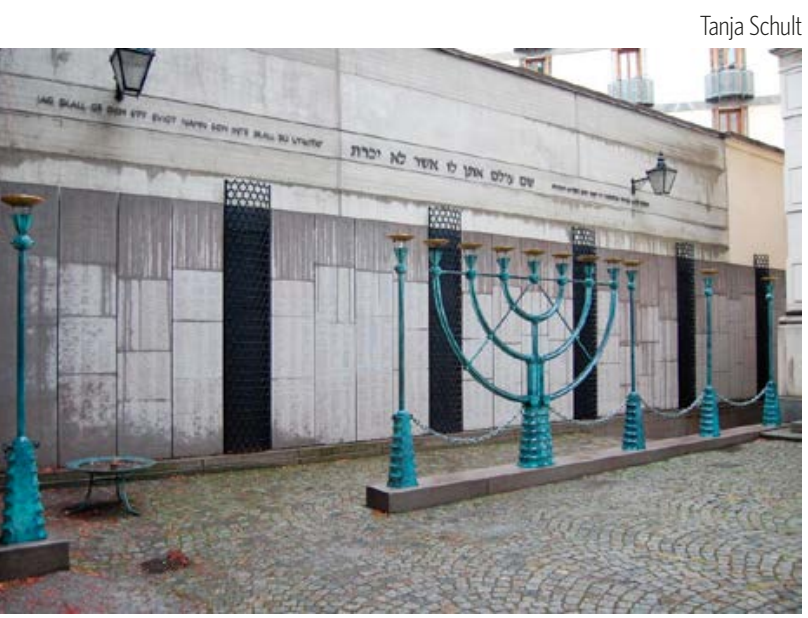

Sivert Lindblom och Gabriel Herdevall, Glöm oss inte (Stockholm 1998).

Glöm oss inte uppfördes r 1998. På platsen framför huvudingången till Stockholms Stora Synagoga möter vi återigen en menora, men denna gång i tredimensionell form och mycket större. Den är 2,40 m hög och inramad av flera lyktor, alla i grön patinerad brons. Det är just denna första del av verket som syns bäst från gatan och som lyckas skapa en förbindelse, trots staketet, med den omgivande staden. Verket restes alltså på enskild mark som ägs av församlingen men det kan ändå ses från gatan. Att väcka de förbipasserandes uppmärksamhet var en av intentionerna hos monumentets upphovsmän, arkitekten Gabriel Herdevall och skulptören Sivert Lindblom (se Lindblom och Herdevall I999: 15). Meningen är att den förbipasserande ska känna sig välkommen att besöka gården.

Tillsammans med synagogan bildar menoran en slags sköld och erbjuder skydd och avskildhet för namnmonumentet. Ytterligare strukturelement är ett bronsfat med småstenar, hämtade från Israel, avsedda att läggas vid monumentet, samt en svartpatinerad bronstavla med information om verket. Tavlan är uppsatt på spaljéer i gjutjärn utformade som Davidsstjärnor, ett återkommande element för att ge struktur åt plattorna i grå bjärlövsgranit längs väggen med de blästrade namnen. På väggen ovanför menoran löper ett bibelcitat på svenska och hebreiska: ”Jag skall giva dem ett evigt namn som icke skall vara utrotat" (Jesaja 56:5). Dessa element fungerar som en "entré" till själva väggmonumentet. Längs väggen löper 56 stora granitplattor som sammanlagt bildar en 42 meter lång vägg. Besökaren tar sig förbi dem, ner i Aaron Isaacs gränd, fram till kanslibyggnaden. Två tavlor tillägnas de offer som dog under eller efter transporten till Sverige. På ytterligare två tavlor finns de namn som lämnades in efter invigningen. Här har uppgifter om årtal, födelseort och dylikt uteslutits för att lämna plats åt så många namn som möjligt. ${ }^{32}$ På nedre delen av granitpostamentet, $\mathrm{i}$ den smala gången mellan synagogan och väggen som angränsar till nöjeslokalen Berns, står namnen på de största nazistiska arbets-, koncentrations- och förintelselägren.

Fler än 8 ooo namn finns på väggen. De är ordnade alfabetiskt utifrån uppgiftslämnarens efternamn. I ett land som undgick Förintelsen konkretiseras händelserna på detta sätt och monumentet blir en plats där Förintelsen särskilt kan kommas ihåg - inte minst av dem som kom till Sverige efter I 945 och fann ett nytt hemland här. Det var deras behov som ledde till att minnesmärket kom till. Monumentet är alltså också ett minnesmärke över deras sorg och saknad efter anhöriga. Det tog tid innan monumentet kunde uppföras och vägen dit var lång. Hur detta gick till och hur minnet av Förintelsen integrerades $i$ hela den svensk-judiska minoriteten och så småningom fick plats i det offentliga rummet i Sverige behandlas i ett kommande nummer av Nordisk Judaistik.

32 Jmf FFÖs informationsbroschyr som finns på föreningens hemsida. Platsen räckte ändå inte för alla namn som lämnades in efter invigningen. 


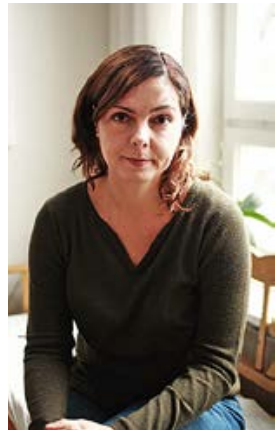

Tanja Schult has a PhD in Scandinavian Studies and Art History. She is the author of A Hero's Many Faces: Raoul Wallenberg in Contemporary Monuments (Palgrave Macmillan 2009/2012) and the editor, with Eva Kingsepp, of Hitler für alle. Populärkulturella perspektiv på Nazityskland, andra världskriget och Förintelsen

(Carlsson Bokförlag 2012) and, with Diana Popescu, of Revisiting Holocaust Representation in the Post-Witness Era (Palgrave Macmillan 2015). Schult's current research project, Making the Past Present: Public Perceptions of Performative Holocaust Commemoration Since the Year 2000 is financed by the Swedish Research Council and situated at the Department of Culture and Aesthetics at Stockholm University.

\section{Referenser}

Assmann, Aleida, 2006. Der Lange Schatten der Vergangenheit. Erinnerungskultur und Geschichtspolitik (München, C.H. Beck).

Bankier, Channa, I 995. "Lärbro - okänd judisk gravplats" i 6 tusen av 6 miljoner.

Ett requiem, red. Romuald Wroblewski (Stockholm, Reproprint AB).

Benz, Wolfgang, 2007. A Concise History of the Third Reich (Berkeley, Los Angeles, London, University of California).

Dahl, Izabela A., 201 3. Ausschluss und Zugehörigkeit. Polnische jüdische Zwangsmigration in Schweden nach dem Zweiten Weltkrieg (Berlin, Metropol Verlag).

Einhorn, Lena, I 999. Handelsresande i liv. Om vilja och vankelmod $i$ krigets skugga (Stockholm, Norstedts).
Følners, Bjarke, 20 I I."Memorials and memorial culture" i Nothing to Speak of: Wartime Experiences of the Danish Jerws 1943-1945, av Sofie Lene Bak (Copenhagen, The Danish Jewish Museum), s. 2 I 5-249.

Föreningen Förintelsens Överlevande i Sverige, hemsida, <http://www.ffo.nu> (läst I I.7.20I6).

"Ghettomonumentet i Warszawa", Judisk krönika I 7(8), I 948.

Gordon, Willy, I 976. Willy Gordon (Järna, meta bokproduktion).

Hancock, Michael R., I 988. "Kärnan och skalet", Judisk krönika 56(4-5), s. 30-3 I.

Holmén, Christian I 998. "Han fruktar en nazistattack. Monument över Förintelsens offer hårdbevakas", Expressen 26.9.1998, s. I3.

"Högtidsdagar i Trondheim", Judisk krönika I6( го), I 947, s. I 86-187.

Judisk krönika 53(I), I985.

Judisk krönika Magasinet I, I99I, s. 2.

"Judiska flygares minne hedrat i Malmö", Judisk krönika I7(I 8), I 948, s. 2 I 7.

"Judiskt gravmonument i Oslo", i Judisk krönika I 8(I-2), I949, s. 24.

Keren Kajemet Sverige - Israelfonden, hemsida, <http://www.kkl.nu> (läst I I.7.20I6).

Leiser, Erwin, I 945. "Ung judisk skulptör", Judisk Tidskrift I 8( I 2), s. 387-389.

— 1950."Willy Gordon", Judisk Tidskrift 23(5), s. I 59-I6I.

Lindblom, Sivert och Gabriel Herdevall, I 999. "Minnesmonumentet. Avskilt och öppet" i Glöm oss inte (Stockholm, Hillelförlaget), s. I 5 .

Neuman, Seth, I 998. "Låt oss minnas våra hädangångna" i Det judiska Stockholm, utg. av David Glück, Aron Neuman och Jacqueline Stare (Stockholm, Judiska museet), s. 36-58.

The Memory of the Holocaust in Sweden (Förintelseminnet i Sverige) - The Holocaust monuments erected in Sweden between 1949 and 2009 reflect the shifting but persistent need felt by survivors of the Nazi genocide to mourn their murdered relatives. The survivors who came to Sweden during or after the war needed a place to grieve, but they also sought acknowledgement of their suffering as well as integration into the Swedish-Jewish community. While they once came accidently to Sweden as a result of persecution, over the years they established their lives here and wanted their memories to be integrated into the society in which they lived. The Holocaust, not least through the commitment of the survivors, became a constant reference point in the Swedish-Jewish community, and because the Holocaust was a benchmark in history and acknowledged as such over time, the survivors' memories were eventually, especially from the 1990s, integrated into the collective memory of Swedish society. The genocide of the European Jews thus also became an important point of reference for the majority of the community. The various Holocaust monuments illustrate how the memory cultures of the minority and the majority slowly approach one another. 
Ringart, Jakob, I 999. ”Om namnmonumentet och dess förverkligande" i Glöm oss inte (Stockholm, Hillelförlaget), s. Io-I 2.

Rubinstein [felstavad som Rubinsten], Harald, I986." 40-års minne. En maning till de unga" i Föreningen 1945 års räddade judar i Malmö. 40-årsjubileum 1946-1986, utgiven av Föreningen 1945 års räddade (Malmö, Föreningen I 945 års räddade judar), s. 5-6.

Rubinstein, Harry, I950."Gravmonument i Malmö över nazismens offer", Judisk krönika I 9(I-2), s. I 2 .

Schult, Tanja, 2009/201 2. A Hero's Many Faces: Raoul Wallenberg in Contemporary Monuments (Basingstoke, New York, Palgrave Mcmillan). 2016."Frühe Holocausterinnerung in Schweden. Denkmäler für Ermordete und Gerettete" i Als der Holocaust noch keinen Namen hatte. Zur frühen Aufarbeitung des NS-Massenmords an Jüdinnen und Juden, utgiven av Regina Fritz, Béla Rásky och Éva Kovács (Wien, New Academic Press), s. $263-284$.

Selling, Jan, 20 Io."'Levande historia' als schwedisches Mahnmal. Von der Vergangenheits- zur Geschichtspolitik" i Ideengeschichte als politische Aufklärung. Festschrift für Wolfgang Wippermann zum 65. Geburtstag, utg. av Stefan Vogt o.a. (Berlin, Metropol), s. 539-567.

Sjögren, Karin, 200 I. Judar i det svenska folkhemmet. Minne och identitet i Judisk krönika 1948-1958 (Eslöv, B. Östlings bokförlag, Symposion).

Sommerfeld, Leopold, I 987 ."Dagsverke på begravningsplatsen", Judisk krönika 55(5), s. 3 I.

Stugart, Martin, I995."Monument ska minna om förintelsen", Dagens Nyheter 4. Io. 995.

Wroblewski, Romuald, sa. "Sista resans näst sista etapp" i The Janusz Korczak Living Heritage Associations hemsida, <fcit.usf. edu/HOLOCAUST/korczak/kkronika/ korcz.htm> (läst I I.7.20I6).

- (red.) I 995.6 tusen av 6 miljoner. Ett requiem (Stockholm, Reproprint $\mathrm{AB}$ ). 